\title{
Oil Spills and Dispersants Can Cause the Initiation of Potentially Harmful Dinoflagellate Blooms ("Red Tides")
}

\author{
Rodrigo Almeda, ${ }^{* \dagger}$ ' Sarah Cosgrove, ${ }^{\ddagger}$ and Edward J. Buskey ${ }^{\ddagger}$ \\ ${ }^{\dagger}$ Centre for Ocean Life, Technical University of Denmark, 2800 Kongens Lyngby, Denmark \\ ${ }^{\ddagger}$ Marine Science Institute, University of Texas at Austin, Port Aransas, Texas 78373, United States
}

Supporting Information

ABSTRACT: After oil spills and dispersant applications the formation of red tides or harmful algal blooms (HABs) has been observed, which can cause additional negative impacts in areas affected by oil spills. However, the link between oil spills and HABs is still unknown. Here, we present experimental evidence that demonstrates a connection between oil spills and HABs. We determined the effects of oil, dispersant-treated oil, and dispersant alone on the structure of natural plankton assemblages in the Northern Gulf of Mexico. In coastal waters, large tintinnids and oligotrich ciliates, major grazers of phytoplankton, were negatively affected by the exposure to oil and dispersant, whereas bloom-forming dinoflagellates (Prorocentrum texanum, P. triestinum, and Scrippsiella trochoidea) notably increased their concentration. The removal of key grazers due to oil and

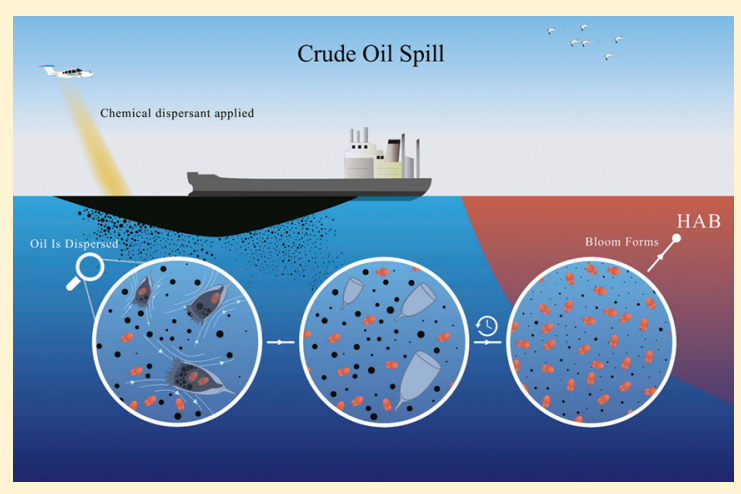
dispersant disrupts the predator-prey controls ("top-down controls") that normally function in plankton food webs. This disruption of grazing pressure opens a "loophole" that allows certain dinoflagellates with higher tolerance to oil and dispersants than their grazers to grow and form blooms when there are no growth limiting factors (e.g., nutrients). Therefore, oil spills and dispersants can act as disrupters of predator-prey controls in plankton food webs and as indirect inducers of potentially harmful dinoflagellate blooms.

\section{INTRODUCTION}

Crude oil pollution in the ocean is a major environmental problem. ${ }^{1-3}$ Oil spills frequently occur in coastal areas, ${ }^{1}$ and plankton are among the first organisms to interact with spilled crude oil. ${ }^{4-13}$ Most biological processes in the ocean are due to planktonic organisms, ${ }^{14}$ and therefore assessing the impact of oil spills on marine ecosystems requires a clear understanding of the effects of oil pollution on planktonic communities. After oil spills and application of chemical dispersants, the formation of "red tides" or harmful algal blooms (HABs) has been reported, for example after the Itxoc I (1979) $)^{15}$ and Deep Water Horizon (DWH, 2010) ${ }^{16}$ oil spills in the Gulf of Mexico and the Bohai Sea spill (2011) in the Yellow Sea. ${ }^{17}$ HABs are proliferations of phytoplankton species that can cause harm in the environment, either by the production of toxins or by deleterious effects due to their high biomass. ${ }^{18-20}$ Thus, HABs can be an additional problem in areas affected by oil spills due to their negative impacts on local ecosystems and economies. ${ }^{18,21}$ However, the connections between oil spills and $\mathrm{HAB}$ events are unknown.

Although $\mathrm{HABs}$ can be natural phenomena, the occurrence of HABs seems to be increasing globally due to anthropogenic causes such as elevated nutrient discharge in coastal waters. ${ }^{18,21-23}$ However, driving factors of HABs are complex and frequently site-specific, and HABs are not exclusively linked to nutrient enrichment. ${ }^{22,23}$ Other factors such as the removal of grazers by pollutants or other stressors can disrupt top-down controls and potentially favor the formation of HABs. Nevertheless, experimental data on the role of top-down control in the formation of HABs are surprisingly scarce. It is often assumed that metazoans such as copepods are the main grazers in planktonic food webs. ${ }^{24}$ However, there is consistent evidence that heterotrophic protists (e.g., ciliates and heterotrophic dinoflagellates), rather than copepods, are the major consumers of phytoplankton, ${ }^{25}$ including $\mathrm{HAB}$ species, $^{26-29}$ in marine systems.

In previous laboratory studies, we found that ciliates were particularly sensitive to crude oil and dispersants compared to other plankton. ${ }^{10}$ These results suggest that given the importance of ciliates as grazers of phytoplankton, oil, and dispersant pollution in the ocean could reduce grazing pressure on phytoplankton and potentially change the structure and dynamics of plankton communities. It has been proposed that phytoplankton blooms are a consequence of physical or chemical perturbations that disrupt biological controls at the level of the microbial loop opening "holes" that allow the blooming of some phytoplankton species ("loophole

Received: January 18, 2018

Revised: March 8, 2018

Accepted: April 16, 2018

Published: April 16, 2018 


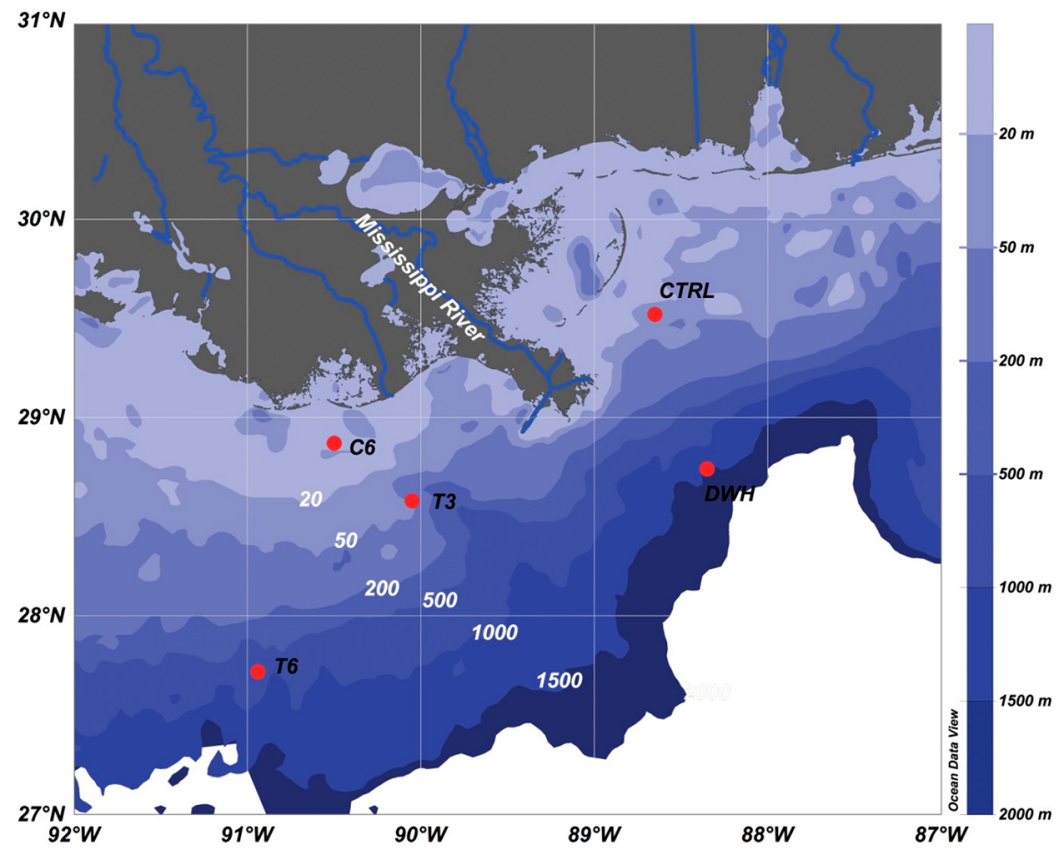

Figure 1. Map with depth contours indicating the plankton sampling sites during the cruise in the northern Gulf of Mexico in May 2013. Sites are located in the area affected by the Deep Water Horizon (DWH) oil spill in April 2010.

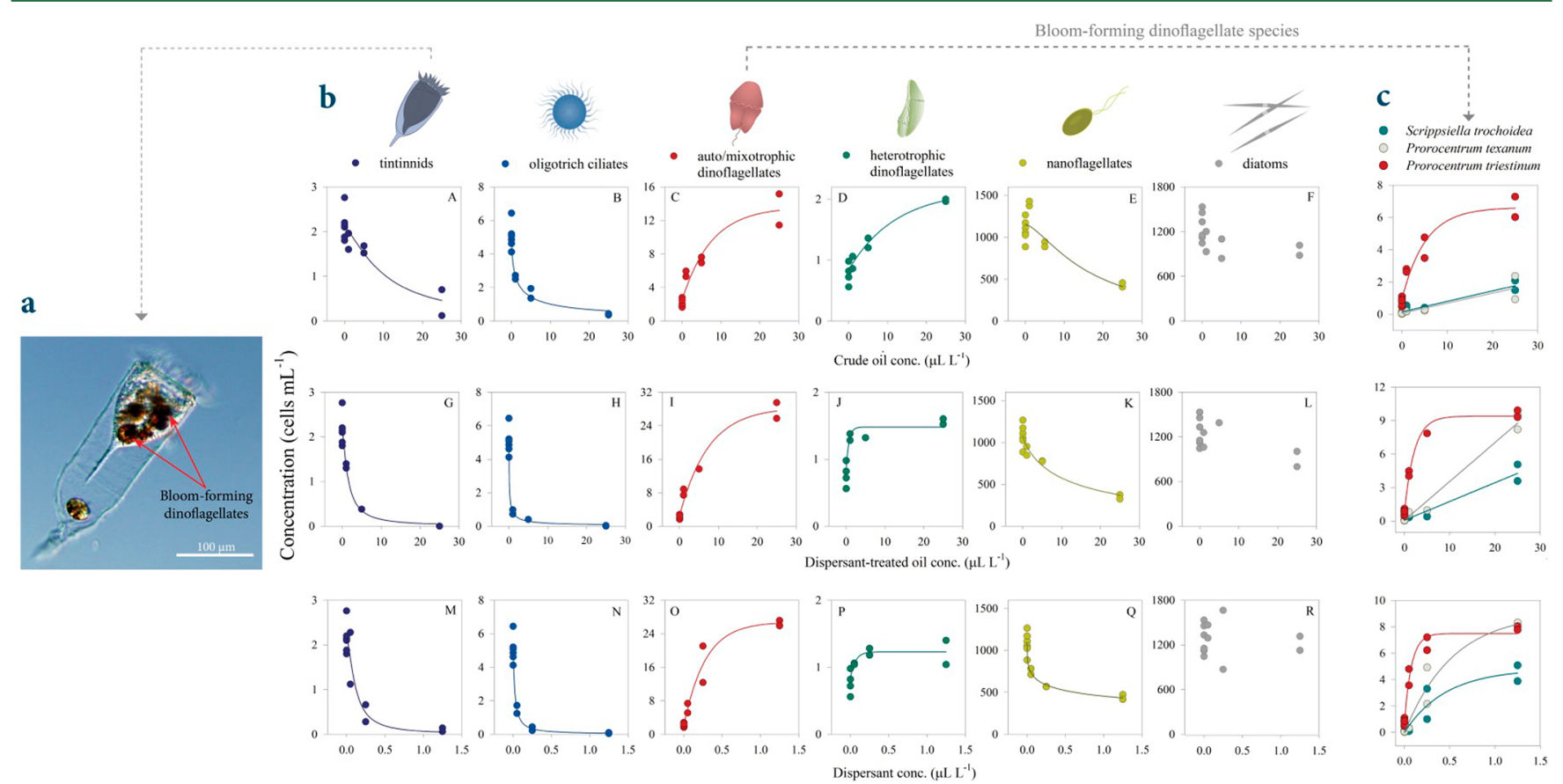

Figure 2. (a) Tintinnid Favella ehrenbergii with ingested cells of bloom-forming dinoflagellates. (b, c) Effects of crude oil (A-F), dispersant-treated oil ( $\mathrm{G}-\mathrm{L})$, and dispersant $(\mathrm{M}-\mathrm{R})$ concentration on cell abundance of different plankton groups (b) and bloom-forming dinoflagellates (c) from natural plankton assemblages collected at the site $\mathrm{C} 6$ after $24 \mathrm{~h}$ of exposure. The cell concentrations are final concentrations after exposure to the studied pollutants, and the regression lines are from eqs 2 and 3 (see extended methods in Supporting Information).

hypothesis"). ${ }^{30}$ This hypothesis cannot explain some phytoplankton blooms such as seasonal diatom blooms in coastal areas or Phaeocystis blooms. ${ }^{31}$ However, some heterotrophic protists can exert a relevant trophic impact on certain bloomforming species, particularly dinoflagellates, ${ }^{26-29}$ and the disruption of grazing pressure can potentially cause the initiation of HABs under certain conditions. ${ }^{32,33}$

Our main hypothesis is that the occurrence of HABs after oil spills and dispersant applications can be the result of a disruption in microzooplankton grazing pressure when there are not bottom-up limiting factors for species of bloom-forming dinoflagellates with a relatively high tolerance to oil and dispersants. Empirical evidence from natural plankton assemblages exposed to realistic concentrations of dispersed oil is needed to fully corroborate this hypothesis. We investigated the effects of oil, dispersant-treated oil, and dispersant on the structure of natural plankton communities from the Gulf of Mexico (Figure 1), with particular emphasis 

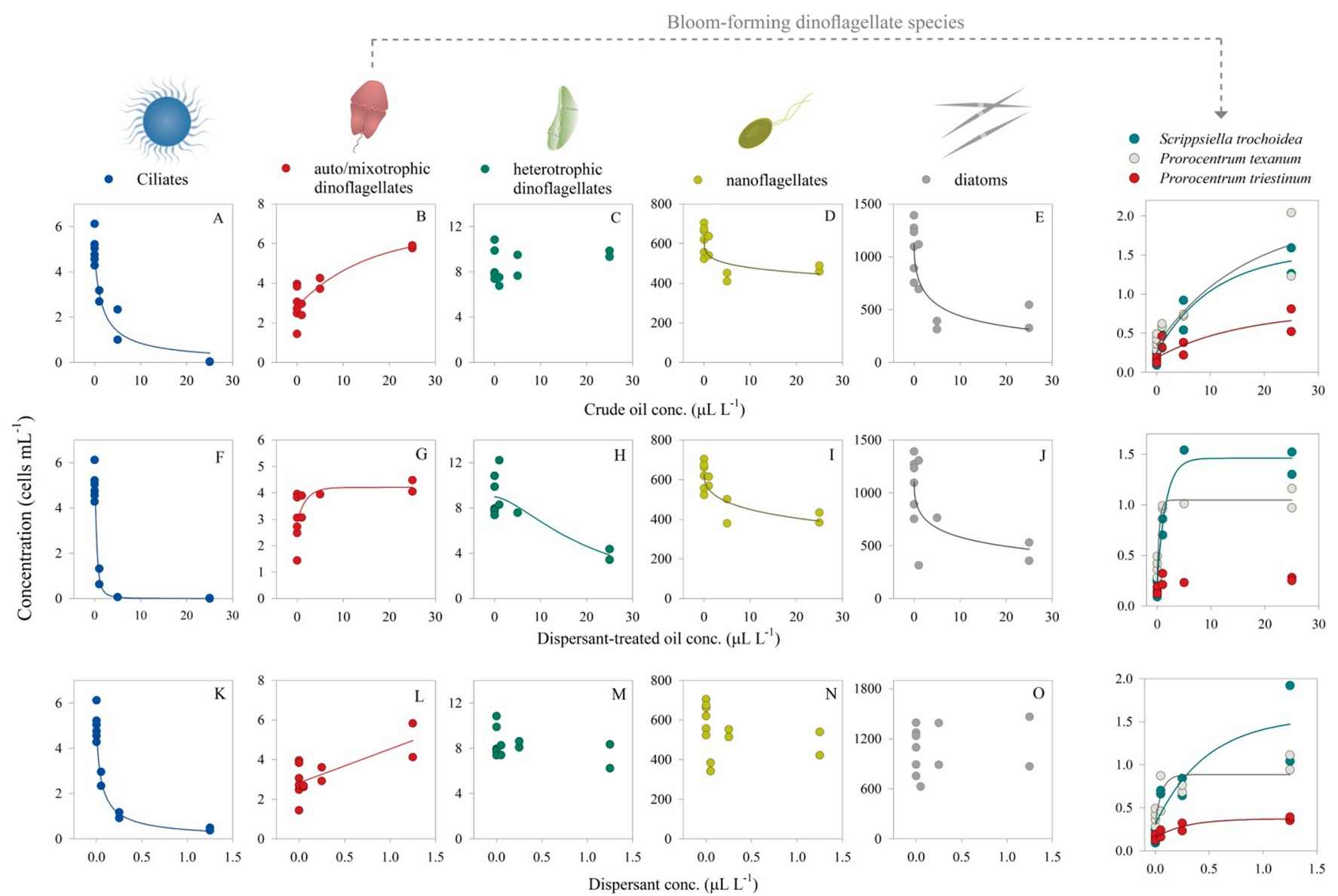

Figure 3. Effects of crude oil, dispersant-treated oil, and dispersant concentration on the cell abundance of different plankton groups (A-O) and bloom-forming dinoflagellates (right panels) from natural plankton assemblages collected at the site CTRL after $24 \mathrm{~h}$ of exposure. The cell concentrations are final concentrations after exposure to the studied pollutants, and the regression lines are from eqs 2 and 3 (see extended methods in Supporting Information).

on heterotrophic protists and bloom-forming dinoflagellates, to evaluate if oil and dispersant can disrupt the grazing control by heterotrophic protists on bloom-forming species and, consequently, allow the initiation of dinoflagellate red tides. We additionally conducted a 12-day laboratory study with one of the dinoflagellate species found in the field study with potential to form blooms after oil spills to fully corroborate that in the absence of grazers some dinoflagellates can reach bloom levels after exposure to dispersed oil concentrations commonly found in the water column after oil spills.

\section{MATERIALS AND METHODS}

Field Study. During a research cruise in May 2013, we conducted $24 \mathrm{~h}$ on-board incubations to determine the effects of different concentrations of crude oil $\left(1,5\right.$, and $\left.25 \mu \mathrm{L} \mathrm{L}^{-1}\right)$, Corexit 9500 dispersant $\left(0.05,0.25\right.$, and $\left.1.25 \mu \mathrm{L} \mathrm{L}^{-1}\right)$, and dispersant-treated oil $\left(1,5\right.$, and $\left.25 \mu \mathrm{L} \mathrm{L}^{-1}\right)$ on the abundance and composition of natural plankton assemblages from coastal and offshore waters in the northern Gulf of Mexico (Figure 1). Specifically, we determined the response to these pollutants of heterotrophic bacteria, cyanobacteria, picoeukaryotes, nanoflagellates, diatoms, ciliates, and dinoflagellates, including bloom-forming dinoflagellates. Test media were prepared as described in Almeda et al. using a recommended dispersant-tooil ratio of $1: 20 .^{10}$ After adding the test media to the corresponding experimental bottles, control and experimental bottles were incubated on-board in a large acrylic incubation container $\left(1.2 \mathrm{~m}^{3}\right)$ containing a plankton wheel $(\sim 2 \mathrm{rpm})$ with open-circuit seawater running through it, thus providing similar exposure to sunlight and in situ temperature for all the bottles in each experiment. Detailed methods are provided in the Supporting Information (SI-Text 1).

Laboratory Study. A laboratory experiment with the toxic dinoflagellate Prorocentrum texanum ${ }^{34}$ was conducted to test the tolerance and ability of this dinoflagellate species to bloom after exposure to dispersed oil. P. texanum was chosen as experimental organism because it was one of the dinoflagellate species found in our field studies with potential for forming blooms after oil spills. The experiment consisted of 12-day laboratory incubations of $P$. texanum culture $(55 \pm 5$ cells $\left.\mathrm{mL}^{-1}\right)$ exposed to crude oil alone $\left(1 \mu \mathrm{L} \mathrm{L}^{-1}\right)$, dispersanttreated crude oil $\left(1 \mu \mathrm{L} \mathrm{L}^{-1}\right)$, and dispersant alone $(0.05 \mu \mathrm{L}$ $\mathrm{L}^{-1}$ ) and in the absence of pollutants (control treatment) and without nutrient limitation. The specific growth rate $\left(\mathrm{d}^{-1}\right)$ of $P$. texanum in each treatment was estimated as the slope of the regression line relating the natural logarithm of cell concentration (cells $\mathrm{mL}^{-1}$ ) and exposure time (days). Detailed methods are provided in SI-Text 2.

\section{RESULTS AND DISCUSSION}

Initial abundance (cells $\mathrm{mL}^{-1}$ ) of the main studied planktonic organisms varied among sites during the field study, with 

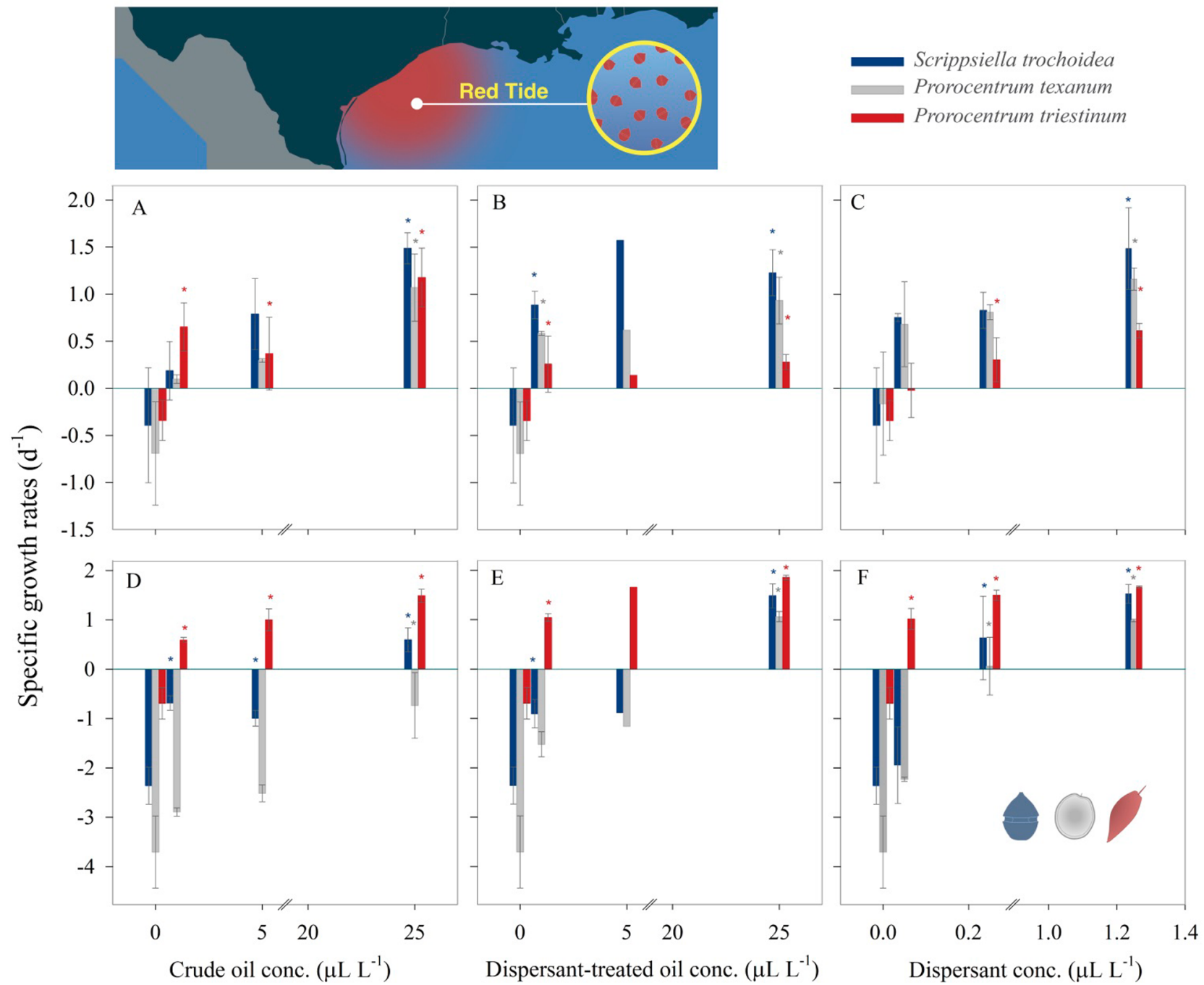

Figure 4. Specific growth rates $\left(\mathrm{d}^{-1}\right.$, in cells) of bloom-forming dinoflagellates when natural plankton assemblages from the site CTRL (A-C) and the site C6 (D-F) were exposed to different concentrations of crude oil, dispersant-treated oil, and dispersant. The asterisk indicates a statistically significant difference in growth rates between the experimental treatment (with pollutants) and the control (absence of pollutants).

ciliates and dinoflagellates being more abundant in the coastal sites C6 and CTRL (Table S1). Marine ciliates, both tintinnids and oligotrichs, were negatively affected by dispersed oil and dispersants in all plankton communities/sites (Figures 2 and 3, Figures S1-S3). These results, together with previous laboratory research on the direct effects of oil and dispersants on single species of ciliates, ${ }^{10}$ demonstrate that marine planktonic ciliates, major grazers of phytoplankton, are highly sensitive to crude oil and dispersants.

In the site C6 (Figure 1), the abundance of the large tintinnid Favella ehrenbergii (length $\sim 340 \mu \mathrm{m}$ ) and oligotrich ciliates decreased with increasing oil or dispersant concentration whereas dinoflagellates, particularly auto/mixotrophic dinoflagellates, increased their concentration (Figure 2). Among the auto-/mixotrophic dinoflagellate species, bloomforming Prorocentrum texanum, P. triestinum, and Scrippsiella trochoidea notably increased their concentration after exposure to oil or dispersant (Figure 2). P. texanum is a recently described new species of bloom-forming toxic dinoflagellate that produces okadaic acid, ${ }^{34}$ a toxin responsible for the diarrheic shellfish poisoning (DSP) in humans. P. triestinum and $S$. trochoidea are generally considered not chemically toxic, but their blooms can cause fish kills and other damage in coastal areas. $^{35-39}$ In addition, S. trochoidea blooms can cause severe lethal effects on shellfish larvae. ${ }^{20}$ In the other coastal study site CTRL (Figure 1), we also found a high number of ciliates, including some large species (e.g., Laboea, length $\sim 90 \mu \mathrm{m}$; Strombidium, length $\sim 40 \mu \mathrm{m}$ ) (Table S1). In the site CTRL the response of ciliates and auto-/mixotrophic dinoflagellates to oil and dispersant followed the same pattern as in station C6, with bloom-forming species ( $P$. texanum, $P$. triestinum, and $S$. trochoidea) more abundant after exposure to oil and dispersants (Figures 2 and 3). Heterotrophic dinoflagellates were more abundant in the CTRL site than in the C6 site and decreased in abundance when exposed to dispersant or dispersant-treated oil (Figure 3). The decrease in abundance of heterotrophic dinoflagellates could also reduce the grazing pressure on bloom-forming dinoflagellates in the CTRL site. In both coastal stations (C6 and CTRL), nanoflagellates decreased in abundance with increasing oil and dispersant concentration, whereas diatoms did not show a clear pattern or decrease in abundance depending on the treatments (Figures 2 and 3, Table S2). 

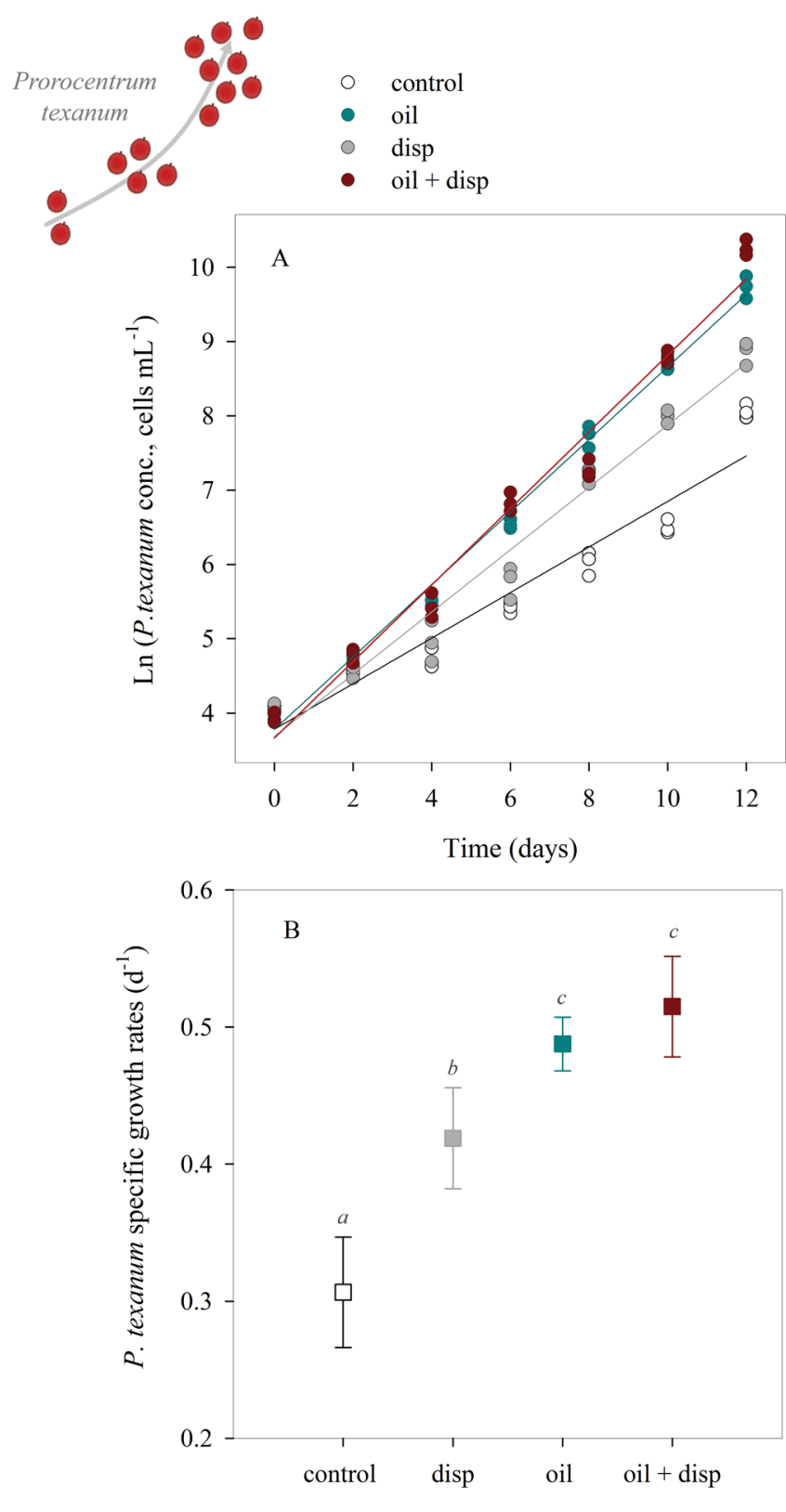

Treatment

Figure 5. Temporal variation in cell concentration (in cells $\mathrm{mL}^{-1}$ ) of a Prorocentrum texanum culture in the absence of pollutants ("control") and after exposure to crude oil alone $\left(1 \mu \mathrm{L} \mathrm{L} \mathrm{L}^{-1}\right.$, "oil"), dispersanttreated crude oil ( $1 \mu \mathrm{L} \mathrm{L}^{-1}$, "oil + disp"), and dispersant alone $(0.05$ $\mu \mathrm{L} \mathrm{L}^{-1}$ "disp") in the laboratory (A). Lines represent the linear regressions of ln-transformed cell concentration versus incubation time (days) (A). Specific growth rates $\left(\mathrm{d}^{-1}\right.$, in cells) of $P$. texanum in the different treatments (B) estimated as the slopes of the linear regressions (A). The error bars indicate the $95 \%$ confidence intervals, and the lowercase italic letters $(a, b, c)$ indicate different statistical groups $(p<0.05)(\mathrm{B})$.

Growth rates of the bloom-forming autotrophic dinoflagellates found in stations C6 and CTRL varied depending on the species and treatments, but specific growth rates of the three bloom-forming dinoflagellate species were higher in the experimental treatments than in controls (Figure 4). This indicates that certain bloom-forming dinoflagellates have a tolerance to these pollutants higher than their main grazers (ciliates and heterotrophic dinoflagellates) which supports our hypothesis that the occurrence of harmful algal blooms after oil spills can be the result of a disruption in microzooplankton grazing pressure on bloom-forming dinoflagellates when there are not bottom-up limiting factors (see extended discussion in SI-Text 3).

In the laboratory study with Prorocentrum texanum, one of the bloom-forming dinoflagellates present in the field study, we found that this species grows exponentially and reached blooms levels $\left(>3000\right.$ cells $\left.\mathrm{mL}^{-1}\right)$ in all the treatments with pollutants after 10 days, reaching a maximum of more than 28000 cells $\mathrm{mL}^{-1}$ in the dispersant-treated oil treatment after 12 days (Figure 5A). Specific growth rates $\left(\mathrm{d}^{-1}\right)$ of $P$. texanum in the experimental treatments were significantly higher than in the control treatments (Figure 5B). Among experimental treatments, growth rates were significantly higher in the treatments with oil than in the treatment with dispersant alone, with no significant differences in growth rates between oil and dispersed-treated oil treatments (Figure 5B). These results indicate that oil and dispersants can stimulate the population growth of $P$. texanum (Figure 5), which could contribute to the rapid formation of blooms in the absence ofgrazers and bottomup limiting factors. In addition, a previous study found that the bloom-forming dinoflagellates Karenia brevis and Prorocentrum minium increase their toxin production after exposure to a crude oil concentration commonly found after oil spills. ${ }^{40}$ The reasons underlying the relatively high tolerance of dinoflagellates to oil and dispersants and the stimulatory effects in growth and toxin production of these pollutants on some bloom-forming dinoflagellate species are unknown. A recent study ${ }^{41}$ suggests that both resilient attached bacteria and freeliving oil degrading bacteria associated with dinoflagellates could help explain the resistance of these planktonic organisms to oil and dispersants (see extended discussion in SI-Text 4). Bacteria communities associated with dinoflagellates can also affect toxin production, ${ }^{42}$ but results from different studies are contradictory. ${ }^{42-44}$

In the offshore sites DWH, T3, and T6 (Figure 1), the abundance of the bloom-forming species was low (Table S1), and the sizes of ciliates (mostly $\leq 20 \mu \mathrm{m}$ ) and auto-/ mixotrophic dinoflagellates (mostly $\sim 15 \mu \mathrm{m}$ ) were smaller than in the coastal sites. In these stations, ciliates, dinoflagellates, and diatoms were negatively affected by oil and particularly dispersant-treated oil and dispersants (Figures S1-S3 and Table S2). Some exceptions were observed in site $\mathrm{T} 3$, a site closer to the coast than T6 and DWH sites, where the bloom-forming dinoflagellate $S$. trochoidea increased in abundance after exposure to crude oil (Figure S1) and where diatoms, mostly Nitzschia/Pseudonitzschia, tended to increase after exposure to dispersed oil and dispersant (Figure S1). Some species of the genera Nitzschia and Pseudonitzschia produce domoic acid, a neurotoxin that can cause harmful effects on marine organisms ${ }^{45}$ and humans. ${ }^{46}$ The different responses of the plankton populations on the studied sites, particularly between coastal and offshore waters, can be explained by differences in plankton community composition (Table S3) and nutrient availability (see extended discussion in SI-Text 5). Growth rates of the cyanobacteria Prochlorococcus and Synechococcus (Figure S4), heterotrophic bacteria, and picoeukaryotes (Figure S5) did not show a clear pattern when exposed to dispersed oil or dispersant in any of the studied sites, although significant differences between treatments were observed occasionally (Figures S4 and S5). For instance, growth rates of heterotrophic bacteria were significantly higher 
when exposed to the higher pollutant concentrations than in the controls in some cases (Figure S5). This increase in bacterial abundance after exposure to oil could be due to a reduction in bacterivorous nanoflagellates and/or to a growth stimulation of oil-degrading bacteria.

According to the estimated median effective concentrations (EC50, Table S2), the combination of oil and dispersant was between 3 and 12 times more toxic than oil alone to ciliates and low concentrations of chemical dispersant alone $(0.02-0.06 \mu \mathrm{L}$ $\mathrm{L}^{-1}$ ) were also toxic to marine ciliates (Table S2). The use of large volumes of the chemical dispersant Corexit 9500 after the DWH oil spill (2010) has increased the concerns about the impact of dispersant on marine ecosystems. Our results and other recent studies indicate that this type of dispersant is more toxic than previously assumed, especially for small planktonic organisms, ${ }^{7,8,13,47,48}$ including microzooplankton. ${ }^{10}$ The formation of red tides after oil spills has been observed in spills where chemical dispersants were applied. ${ }^{15-17}$ Also, a decrease in marine ciliate abundance was observed after a chemically dispersed oil spill occurred in 2012 in the southwest coast of Singapore. ${ }^{49}$ Altogether this indicates that marine planktonic ciliates are negatively affected by low concentrations of dispersants and consequently, the disruption of grazing control on bloom-forming species in marine food webs would increase when oil is chemically dispersed. Therefore, the use of dispersant would increase the probability of HAB occurrence after spills when the environmental conditions are appropriate for bloom-forming dinoflagellates to grow.

To conclude, we would like to emphasize that the effects of oil spills and dispersants on plankton communities varied depending on the multiple physical, chemical, and biological factors. ${ }^{1,5,50}$ The occurrence of an oil spill and the disruption of top-down controls will not always cause a harmful algal bloom since the potential occurrence and magnitude of a dinoflagellate bloom would depend on the specific circumstances of a spill, including the environmental conditions, nutrient availability, and plankton community composition. However, the possibility of formation of harmful algal blooms due to planktonic food web disruption should, at least, be taken into consideration when evaluating the potential impacts of oil spills on marine environments. Oil spills and dispersants can clearly disrupt the grazing control of heterotrophic protists (e.g., ciliates) on certain bloom-forming species and promote the initiation of potentially harmful dinoflagellate blooms after spills when there are not limiting bottom-up factors. Therefore, crude oil and dispersants can act as disrupters of plankton food webs and indirect inducers of harmful dinoflagellate blooms. Disruption of microzooplankton grazing control in plankton food webs as a result of petroleum pollution (e.g., oil spills, wastewater, bilge waters) or other toxicants should be considered as an additional factor to understand the causes of increasing occurrence of harmful dinoflagellate blooms in coastal waters with intense anthropogenic pressure.

\section{ASSOCIATED CONTENT}

\section{S Supporting Information}

The Supporting Information is available free of charge on the ACS Publications website at DOI: 10.1021/acs.est.8b00335.

Text 1-5, Tables S1-S3, and Figures S1-S5 (PDF)

\section{AUTHOR INFORMATION}

\section{Corresponding Author}

*E-mail: roal@aqua.dtu.dk, ralmeda2010@live.com.

ORCID $\odot$

Rodrigo Almeda: 0000-0002-0090-112X

Notes

The authors declare no competing financial interest.

\section{ACKNOWLEDGMENTS}

We thank Cammie Hyatt, Darren Henrichs, and Albert Reñé for their help with the species identification and Rocio Rodriguez for help with the analysis of plankton samples. We thank the crew of the R/V Pelican for their assistance and Zhanfei Liu for his role as chief scientist during the cruise and for providing CTD data (NSF grant, OCE\# 1129659). We also thank Tracey Saxby, Kim Kraeer, Jane Thomas, Jane Hawkey (Integration and Application Network, University of Maryland Center for Environmental Science, http://ian.umces.edu/ imagelibrary/), and Devon Burroughs for providing some of the vector graphics used in the figures. This research was made possible by a grant from The Gulf of Mexico Research Initiative. Data are publicly available through the Gulf of Mexico Research Initiative Information \& Data Cooperative (GRIIDC) at https://data.gulfresearchinitiative.org (doi: $10.7266 /$ N71 V5C17). This work was further supported by a DFF-Individual postdoctoral grant (17023) from the Danish Council for Independent Research to R.A., a Marie Curie IntraEuropean fellowship from the People Programme of the European Union's Seventh Framework Programme FP7/20072013/under REA grant agreement number 6240979 to R.A., and a Hans Christian Ørsted Postdoctoral fellowship from Technical University of Denmark to R.A. The Centre for Ocean Life is a VKR Centre of Excellence funded by the Villum Foundation.

\section{REFERENCES}

(1) National Research Council. Oil in the Sea III: Inputs, Fates, and Effects; National Academy Press: Washington, DC, 2003.

(2) Joye, S. B. Deepwater Horizon, 5 years on. Science 2015, 349, $592-593$.

(3) Allan, S. E.; Smith, B. W.; Anderson, K. A. Impact of the Deepwater Horizon oil spill on bioavailable polycyclic aromatic hydrocarbons in Gulf of Mexico coastal waters. Environ. Sci. Technol. 2012, 46, 2033-2039.

(4) Conover, R. J. Some relations between zooplankton and bunker $\mathrm{C}$ oil in Chedabucto Bay following the wreck of the tanker Arrow. J. Fish. Res. Board Can. 1971, 28, 1327-1330.

(5) Lee, R. F.; Köster, M.; Paffenhöfer, G. A. Ingestion and defecation of dispersed oil droplets by pelagic tunicates. J. Plankton Res. 2012, 34, 1058-1063.

(6) Almeda, R.; Wambaugh, Z.; Wang, Z. C.; Hyatt, C.; Liu, Z. F.; Buskey, E. J. Interactions between zooplankton and crude oil: toxic effects and bioaccumulation of polycyclic aromatic hydrocarbons. PLoS One 2013, 8, e67212.

(7) Almeda, R.; Wambaugh, Z.; Chai, C.; Wang, Z.; Liu, Z. F.; Buskey, E. J. Effects of crude oil exposure on bioaccumulation of polycyclic aromatic hydrocarbons and survival of adult and larval stages of gelatinous zooplankton. PLoS One 2013, 8, e74476.

(8) Almeda, R.; Baca, S.; Hyatt, C.; Buskey, E. J. Ingestion and sublethal effects of physically and chemically dispersed crude oil on marine planktonic copepods. Ecotoxicology 2014, 23, 988-1003.

(9) Almeda, R.; Bona, S.; Foster, C.; Buskey, E. J. Dispersant Corexit $9500 \mathrm{~A}$ and chemically dispersed crude oil decreases the growth rates of meroplanktonic barnacle nauplii (Amphibalanus improvisus) and 
tornaria larvae (Schizocardium sp.). Mar. Environ. Res. 2014, 99, 212217.

(10) Almeda, R.; Connelly, T. L.; Buskey, E. J. Novel insight into the role of heterotrophic dinoflagellates in the fate of crude oil in the sea. Sci. Rep. 2015, 4, 7560.

(11) Almeda, R.; Hyatt, C.; Buskey, E. J. Toxicity of dispersant Corexit 9500A and crude oil to marine microzooplankton. Ecotoxicol. Environ. Saf. 2014, 106, 76-85.

(12) Almeda, R.; Connelly, T. L.; Buskey, E. J. How much crude oil can zooplankton ingest? Estimating the quantity of dispersed crude oil defecated by planktonic copepods. Environ. Pollut. 2016, 208, 645654.

(13) Almeda, R.; Harvey, T. E.; Connelly, T. L.; Baca, S.; Buskey, E. J. Influence of UVB radiation on the lethal and sublethal toxicity of dispersed crude oil to planktonic copepod nauplii. Chemosphere 2016, 152, 446-458.

(14) Parsons, T. R.; Takahashi, M. Biological Oceanographic Processes; Pergamon Press: Oxford, UK, 1973.

(15) Jernelöv, A.; Lindén, O. Ixtoc I: A case study of the world's largest oil spill. Ambio. 1981, 10, 299-306.

(16) FWC Fish and Wildlife Research Institute. Ceratium species bloom, offshore Florida Panhandle, May 10, 2010. Available at: https://www.flickr.com/photos/myfwc/6442824005 (accessed: Dec 2017).

(17) Guo, J.; Liu, X.; Xie, Q. Characteristics of the Bohai Sea oil spill and its impact on the Bohai Sea ecosystem. Chin. Sci. Bull. 2013, 58, 2276-2281.

(18) Hallegraeff, G. M. A review of harmful algal blooms and their apparent global increase. Phycologia 1993, 32, 79-99.

(19) Smayda, T. J. Harmful algal blooms: Their ecophysiology and general relevance to phytoplankton blooms in the sea. Limnol. Oceanogr. 1997, 42, 1137-1153.

(20) Tang, Y. Z.; Gobler, C. J. Lethal effects of Northwest Atlantic Ocean isolates of the dinoflagellate, Scrippsiella trochoidea, on Eastern oyster (Crassostrea virginica) and Northern quahog (Mercenaria mercenaria) larvae. Mar. Biol. 2012, 159, 199-210.

(21) Hoagland, P.; Scatasta, S. The economic effects of harmful algal blooms. In Ecology of Harmful Algae; Graneli, E., Turner, J. T., Eds.; Springer: Berlin, 2006; pp 391-402.

(22) Davidson, K.; Gowen, R. J.; Harrison, P. J.; Fleming, L. E.; Hoagland, P.; Moschonas, G. Anthropogenic nutrients and harmful algae in coastal waters. J. Environ. Manage. 2014, 146, 206-216.

(23) Michalak, A. M. Study role of climate change in extreme threats to water quality. Nature 2016, 535, 349-350.

(24) Turner, J. T.; Graneli, E. "Top-down" predation control on marine harmful algae. In Ecology of Harmful Algae; Graneli, E., Turner, J. T., Eds.; Springer: Berlin, 2006; pp 355-366.

(25) Calbet, A.; Landry, M. Phytoplankton growth, microzooplankton grazing, and carbon cycling in marine systems. Limnol. Oceanogr. 2004, 49, 51-57.

(26) Calbet, A.; Vaque, D.; Felipe, J.; Vila, M.; Sala, M. M.; Alcaraz, M.; Estrada, M. Relative grazing impact of microzooplankton and mesozooplankton on a bloom of the toxic dinoflagellate Alexandrium minutum. Mar. Ecol.: Prog. Ser. 2003, 259, 303-309.

(27) Jeong, H. J.; Yoon, J. Y.; Kim, J. S.; Yoo, Y. D.; Seong, K. A. Growth and grazing rates of the prostomatid ciliate Tiarina fusus on red-tide and toxic algae. Aquat. Microb. Ecol. 2002, 28, 289-297.

(28) Johnson, M. D.; Rome, M.; Stoecker, D. K. Microzooplankton grazing on Prorocentrum minimum and Karlodinium micrum in Chesapeake Bay. Limnol. Oceanogr. 2003, 48, 238-248.

(29) Kim, J. S.; Jeong, H. J. Feeding by the heterotrophic dinoflagellates Gyrodinium dominans and G. spirale on the red-tide dinoflagellate. Mar. Ecol.: Prog. Ser. 2004, 280, 85-94.

(30) Irigoien, X.; Flynn, K. J.; Harris, R. P. Phytoplankton blooms: a 'loophole' in microzooplankton on grazing impact? J. Plankton Res. 2005, 27, 313-321.

(31) Sherr, E. B.; Sherr, B. F. Capacity of herbivorous protists to control initiation and development of mass phytoplankton blooms. Aquat. Microb. Ecol. 2009, 57, 253-262.
(32) Buskey, E. J.; Montagna, P. A.; Amos, A. F.; Whitledge, T. E. Disruption of grazer populations as a contributing factor to the initiation of the Texas brown tide algal bloom. Limnol. Oceanogr. 1997, 42, 1215-1222.

(33) Buskey, E. J. How does eutrophication affect the role of grazers in harmful algal bloom dynamics? Harmful Algae 2008, 8, 152-157.

(34) Henrichs, D. W.; Scott, P. S.; Steidinger, K. A.; Errera, R. M.; Abraham, A.; Campbell, L. Morphology and phylogeny of Prorocentrum texanum sp nov (Dinophyceae): a new toxic dinoflagellate from the gulf of Mexico coastal waters exhibiting two distinct morphologies. J. Phycol. 2013, 49, 143-155.

(35) Burkholder, J. M.; Glibert, P. M.; Skelton, H. M. Mixotrophy, a major mode of nutrition for harmful algal species in eutrophic waters. Harmful Algae 2008, 8, 77-93.

(36) Hallegraeff, G. M. Harmful algal blooms in the Australian region. Mar. Pollut. Bull. 1992, 25, 186-190.

(37) Lu, S. H.; Hodgkiss, I. J. Harmful algal bloom causative collected from Hong Kong waters. Hydrobiologia 2004, 512, 231-238.

(38) Stephen, V. C.; Hockey, P. A. R. Evidence for an increasing incidence and severity of Harmful Algal Blooms in the southern Benguela region. S. Afr. J. Sci. 2007, 103, 223-231.

(39) Yan, T.; Ming-Jiang, Z.; Jing-Zhong, Z. A national report on harmful algal blooms in China. In Harmful Algal Blooms in the PICES Region of the North Pacific; Taylor "Max", F. J. R., Trainer, V. L., Eds.; PICES Scientific Report No. 23; North Pacific Marine Science Organization: Sidney, BC, Canada, 2002; pp 119-128.

(40) Ozhan, K.; Bargu, S. Responses of sympatric Karenia brevis, Prorocentrum minimum, and Heterosigma akashiwo to exposure of crude oil. Ecotoxicology 2014, 23, 1387-1398.

(41) Severin, T.; Bacosa, H. P.; Sato, A.; Erdner, D. L. Dynamics of Heterocapsa sp. and associated attached and free-living bacteria under the influence of dispersed and undispersed crude oil. Lett. Appl. Microbiol. 2016, 63, 419-425.

(42) Uribe, P.; Espejo, R. T. Effect of associated bacteria on the growth and toxicity of Alexandrium catenella. Appl. Environ. Microbiol. 2003, 69, 659-62.

(43) Dantzer, W. R; Levin, R. E. Bacterial influence on the production of paralytic shellfish toxins by dinoflagellated algae. J. Appl. Microbiol. 1997, 83, 464-69.

(44) Wang, C. H.; Wang, Y. Y.; Sun, Y. Y.; Xie, X. T. Effect of antibiotic treatment on toxin production by Alexandrium tamarense. Biomed. Environ. Sci. 2003, 16, 340-47.

(45) Landsberg, J. H. The effects of harmful algal blooms on aquatic organisms. Rev. Fish. Sci. 2002, 10, 113-390.

(46) Quilliam, M. A.; Wright, J. L. C. The amnesic shellfish poisoning mystery. Anal. Chem. 1989, 61, 1053A-1060A.

(47) Rico-Martinez, R.; Snell, T. W.; Shearer, T. L. Synergistic toxicity of Macondo crude oil and dispersant Corexit 9500A® to the Brachionus plicatilis species complex (Rotifera). Environ. Pollut. 2013, 173, 5-10.

(48) Goodbody-Gringley, G.; Wetzel, D. L.; Gillon, D.; Pulster, E.; Miller, A.; Ritchie, K. B. Toxicity of Deepwater Horizon Source Oil and the Chemical Dispersant, Corexit ${ }^{\circledR}$ 9500, to Coral Larvae. PLoS One 2013, 8, e45574.

(49) Schmoker, C.; Russo, F.; Drillet, G.; Trottet, A.; Mahjoub, M. S.; Hsiao, S. H.; Larsen, O.; Tun, K.; Calbet, A. Effects of eutrophication on the planktonic food web dynamics of marine coastal ecosystems: the case study of two tropical inlets. Mar. Environ. Res. 2016, 119, 176-188.

(50) Ozhan, K.; Parsons, M. L.; Bargu, S. How were phytoplankton affected by the Deepwater Horizon oil spill? BioScience 2014, 64, 829836. 